\title{
Microscopic Anatomy of the Male Reproductive System in Echinolittorina peruviana (Mollusca: Caenogastropoda)
}

\author{
Anatomía Microscópica del Sistema Reproductor Masculino \\ de Echinolittorina peruviana (Mollusca: Caenogastropoda)
}

Viviana M. Castillo \& Donald I. Brown

\begin{abstract}
CASTILLO, V. M. \& BROWN, D. I. Microscopic anatomy of the male reproductive system in Echinolittorina peruviana (Mollusca: Caenogastropoda). Int. J. Morphol., 26(2):423-432, 2008.

SUMMARY: Echinolittorina peruviana (Lamarck, 1822), a gonochoric representative of the Littorinidae on the SE Pacific coast, has a male reproductive system adapted for internal fertilization. We describe this system at both macro- and microscopic levels, particularly the compartmentalized organization of the gonad, and the morphology of the penis. The male reproductive system has a variegated conical gonad-digestive gland complex. The gonad presents three compartments, 1) gametogenic acinar among the glandular acini, 2) periacinar with a layer of fusiform somatic cells and, 3) interacinar with glycogen storage cells shared with glandular acini. Spermatogenesis occurs within the acinar gametogenic compartment, with the germinal line organized in centripetal form towards the lumen. The seminal vesicle stores the products of spermatogenesis; in its cephalic region the euspermatozoa are united to the epithelium and the paraspermatozoa are distributed in the lumen. A short duct connects the seminal vesicle to the prostate gland that is open to the pallial cavity over its entire length. The anterior zone of the prostate gland is joined to the cervical spermatic groove that runs along the neck of the snail through the right pallial region; this continues as the penile spermatic groove, ascending from the base to the point of the penis. The penis is acutely conical and unpigmented; towards the anterior and adjacent to its base there is a glandular complex with a mamilliform process and a discoidal glandular region. The secretion from the discoidal region is transformed in a spicule of unknown function, whose histology is described here for the first time. The mamilliform process is formed by the spicular projection and a connective-muscle tissue band which surrounds it and separates it from the discoidal follicular glandular region; the follicular secretion crosses this band and is incorporated into the epithelium which lines the interior of the process.
\end{abstract}

KEY WORDS: Mollusca; Microscopic anatomy; Male reproductive system; Littorinidae.

\section{INTRODUCTION}

The evolution of internal fertilization in the animal kingdom is a reproductive strategy that includes the organization of a complex reproductive system adapted for copulation. The structural complexity associated with the male reproductive system, besides its association with the habit of internal fertilization, includes the organization of a compartmentalized gonad which is able to provide a specialized environment within which highly species-specific gametes are formed (Brown, 1990); an example of this is the introspermatozoan, characteristic of the Caenogastropoda. These molluscs have become adapted by developing a male reproductive system, which includes organs of transport that connect the gonad with a conical penis specialized for copulation (see examples in Fretter, 1941; Fretter \& Graham, 1994; Linke, 1933), showing a high morphological and structural diversity among families. Among these, the Littorinidae exhibit diverse patterns of organization of the reproductive system among its representatives; these patterns have been considered taxonomically relevant for defining the phylogeny of this family (Reid, 1989). The male reproductive systems of the gonochoric representatives of the Littorinidae include: (1) a branched gonad among the tubules of the digestive gland, (2) a seminal vesicle in which the euspermatozoa are stored, (3) a prostate gland, and (4) a conical penis located under the right tentacle of the animal (Fretter \& Graham). Glands that are mamilliform in appearance have been associated with the penis, located in a row on its ventral surface, as well as along its length; the number of these glands constitutes a taxonomic character for the Littorinidae (Buckland-Nicks 
\& Worthen, 1993; Fretter \& Graham; Reid, 1989 and 2002). Penile morphology in the littorinids has been considered to be its' most important taxonomic character (Reid, 1989). In spite of the fact that the family Littorinidae is one of the most highly studied within the Caenogastropoda, studies describing the histological organization of the gonad, the reproductive system, and the body of littorinids from the southern hemisphere are scarce, and relevant information is limited.

In the present study we describe the male reproductive system of Echinolittorina peruviana, a common inhabitant of the SE Pacific coast of South America, providing anatomical observations at macro- and microscopic levels, emphasizing its' organization and the morphology of the penis.

\section{MATERIAL AND METHOD}

Adult males of Echinolittorina peruviana were collected directly from the rocky intertidal zone at Carvallo beach near Valparaíso, Chile ( $33^{\circ} 1^{\prime}$ 'S, $71^{\circ} 38^{\prime}$ O). Freshly collected snails were processed without delay for making observations using light microscopy.

Macroscopic analyses. Specimens were anesthetized for 30 minutes, at $4^{\circ} \mathrm{C}$, in a $1: 1$ solution of sea water and $7.5 \%$ aqueous $\mathrm{Cl}_{2} \mathrm{Mg}$ (Pantín, 1967) and then fixed in Backer's marine calcium formol (Pantín) at $4^{\circ} \mathrm{C}$. The specimens were then dissected in order to prepare drawings and take photographs.

Histological Analyses. Routine methods for light microscopy, entire specimens and transversally sectioned, and portions of the gonad-digestive gland complex were fixed for 24 hours in Bouin's solution. Following fixation, the samples were rinsed in $70 \% \mathrm{EtOH}$ and dehydrated in an increasing series of ethanol concentrations, followed by clearing in butanol and embedding in Paraplast Plus for histological sectioning (Gabe, 1968).

Serial histological sections $5 \mu \mathrm{m}$ in thickness were taken each $75 \mu \mathrm{m}$ through the samples and were mounted on microscope slides. The preparations were processed following routine histological procedure, and stained by a trichrome method to observe topographic coloration, and finally dehydrated, cleared, and mounted to obtain permanent preparations (Valderrama et al., 2004). Transverse and sagittal serial histological sections (Fig.1A) were examined by light microscopy in order to characterize the microanatomy.
Histochemical identification of glycogen: PAS-H (Periodic acid- Schiff-hematoxylin) staining. Small portions of tissue representing the gonad -digestive gland complex and the seminal vesicle were fixed in Gendre (Gabe) at $4^{\circ} \mathrm{C}$ for seven hours, and histological preparations were made as described above. Two sets of preparations bearing consecutive sections of each specimen were de-paraffinated and hydrated. One set of preparations was submitted to two hours of $0.1 \%$ salivary amylase digestion at $37^{\circ} \mathrm{C}$; and the other remained as an undigested control. Both sets of preparations were then rinsed in distilled water and stained with PAS-H (Harris' hematoxylin as a nuclear stain) for the recognition of glycogen (Gabe). The preparations were finally dehydrated, cleared, and mounted in resin. The histological preparations were examined using light microscopy for evidence of the presence of glycogen as noted by a purple red color within the gonadal and seminal vesicle tissue.

\section{RESULTS}

General anatomy of the male reproductive system. The gonad-digestive gland complex of the male E. peruviana has a conical-spiral morphology (Fig.1A), with variegated orange-dark brown coloration. The orange coloration represents the gonadal tissue, while the digestive gland tissue is dark brown (Figs. 2A, 2B). The male gonad is branched between the digestive gland; it is located above the remainder of the visceral mass. The gonad is accompanied by a whitishcoiled duct, the seminal vesicle, which is clearly visible leading toward the extreme posterior of the columellar muscle of the shell (Figs.1A; 2A). Toward the anterior, and open to the pallial cavity, lies a voluminous structure with a globular appearance, the prostate gland (Figs. 1A;2A), which is located above the columellar muscle of the shell. The cervical spermatic groove lies anterior to the prostate gland, and runs to the neck of the snail, ascending along the dorsal side from the base of the penis (penile spermatic groove) to its tip (Fig 1A). The penis is located at the base of the right eye tentacle (Figs. 1A, B; 2B) and is seen as a white, pointed, conical structure. Toward the anterior, and adjacent to the base of the penis there is a structure (Figs. 1A, C; 2B) formed by a region having a mamilliform appearance (mamilliform process), and next to this there is a discoidal region (Fig.1C).

\section{Histological organization of the male reproductive} system. Male gonad. The male gonad has a fundamentally acinar organization among the acini of the digestive gland (Fig. 2C). Three compartments can be distinguished within the gonad (Figs. 2D, F, I): a) gametogenic or acinar; b) perigametogenic or periacinar and c) intergametogenic or interacinar. 

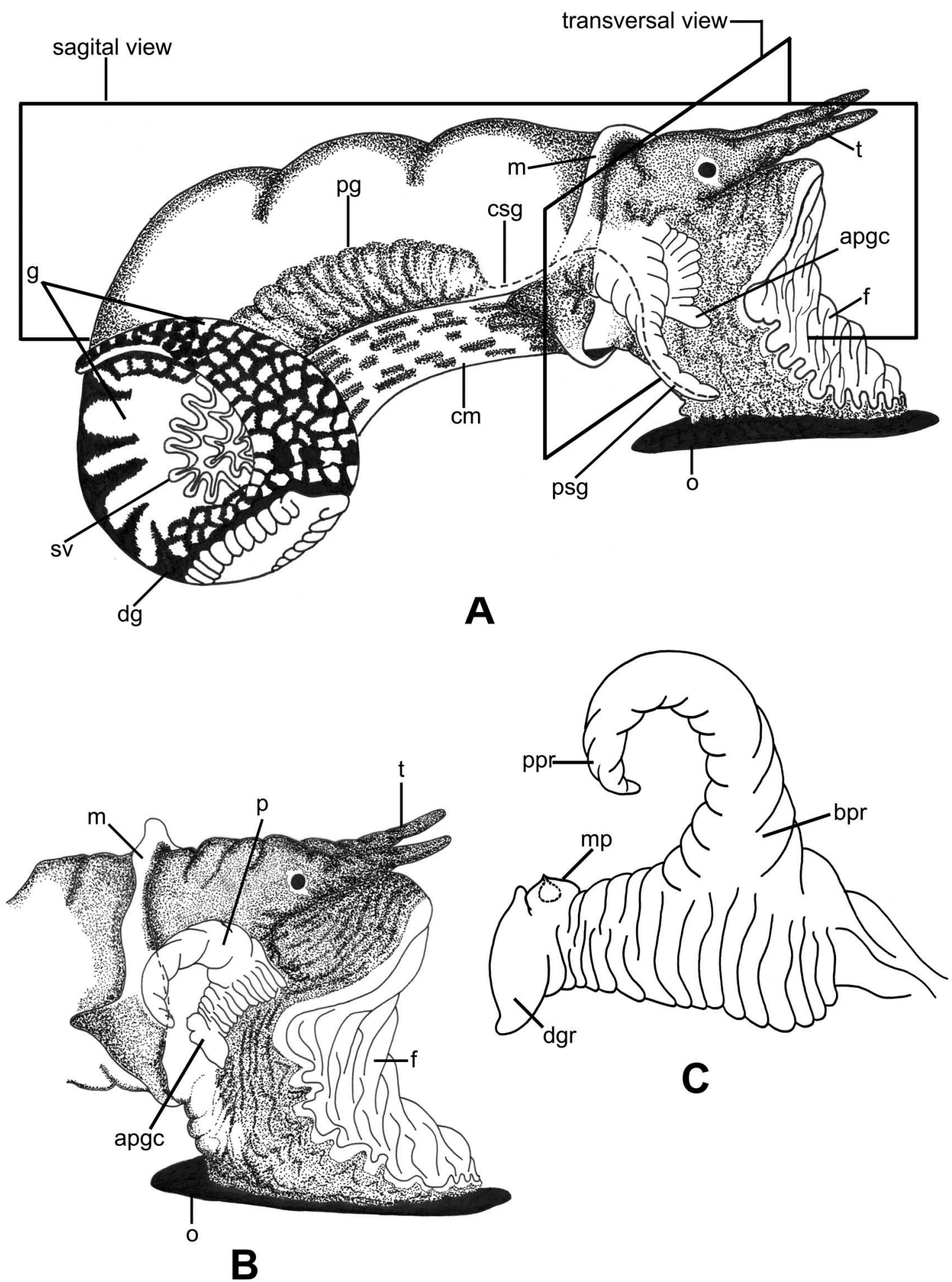

Fig. 1. Echinolittorina peruviana. Male reproductive system. A. Diagram of the general organization of the male reproductive system, showing the locations of the penile and cervical grooves (dotted line). B. Location of the penis. C. Morphology of the penis and annex glandular complex. The proportions of the structures are not shown to scale.

KEY : apgc - annex penile glandular complex; bpr - basal penile region; $\mathrm{f}$ - foot; $\mathrm{ppr}$ - pointed penile region; $\mathrm{g}$ - gonad; me - mantle edge; $\mathrm{mp}$ - mamilliform process; $\mathrm{o}$ - operculum, $\mathrm{p}$ - penis; $\mathrm{pg}$ - prostate gland; psg - penile sperm groove; sv - seminal vesicle; $\mathrm{t}$ - tentacle. 
The gametogenic compartment is located among the tubules of the digestive gland; the acinus is its' basic morphological unit, having a globous appearance, and is found intimately interacting with the periacinar and interacinar compartments (Figs. 2D, F). In this, the germinal cells interact with the somatic Sertoli-like cells in a centripetal organization towards the lumen of the acinus (Fig. 2F, I, K). There was a PAS-positive reaction in certain zones of the cytoplasm of the acinar somatic Sertoli-like cells, in elongated spermatids, and in the principal segment of the euspermatid flagellae (Figs. 2G, J, K). When consecutive segments were submitted to glycogen digestion with salivary amylase, there was negative PAS reaction in these zones (Fig. $2 \mathrm{H})$. On the contrary, the paraspermatozoa in this compartment showed a negative PAS reaction both in sections submitted to PAS staining (Figs. 2G, J) and those submitted to amylase digestion (Fig. 2H). A thin basal lamina, which was PAS positive both with and without amylase digestion surrounds the acinus, and this is underlain by fusiform somatic cells, which form the periacinar compartment (Figs. 2J, K).

The interacinar compartment is formed of a matrix of vesicular somatic cells, forming a surrounding tissue, by which the other compartments are also surrounded (Figs. 2D, 2F, 2I). The cells typically show a strong PAS reaction (Figs. 2E, 2G, 2J), which is not present when consecutive sections are submitted to amylase digestion (Fig. 2H).

Seminal vesicle. This organ is a coiled duct (Fig. 2A), which contains the euspermatozoa and paraspermatozoa on its' lumen. It is lined with a monostratified epithelium, which can vary from slightly squamous to cylindrical (Figs. 2D, F). Histological sections of this organ when treated with the PAS stain, shows its internal epithelial lining and the principal flagellar segment of the euspermatozoa to react positively to PAS (Figs. 2E, G); this reaction was negative on sections submitted to glycogen digestion (Fig. 2H). The paraspermatozoa, similarly to the gametogenic compartment, were PAS negative (Figs. 2G, H).

In the extreme anterior of the seminal vesicle (cephalic direction) next to the prostate gland, there is variation in the organization of the euspermatozoa and the paraspermatozoa. The euspermatozoa occur separately from the paraspermatozoa and are joined to the epithelium which lines the duct (Figs. 3A, B), taking up an organization similar to that observed in the seminal receptacle of females of this species, where the euspermatozoa occur joined to the internal epithelial lining (Fig. 3C). In this region of the seminal vesicle, the paraspermatozoa occur grouped in the lumen of the duct, and surrounded by the euspermatozoa anchored to the epithelium (Figs. 3A, 3B). In this portion of the seminal vesicle the epithelial lining is simple and squamous in structure (Fig. 3B). This region continues with a duct (Fig. 3D) lined by simple ciliated cuboidal epithelium, which connects the seminal vesicle with the posterior portion of the prostate gland.

Prostate gland. This gland is located in the right lateral pallial region, upon the columellar muscle (Fig. 1A).

It is lined internally by a highly pseudostratified cylindrical epithelium, which is ciliated and highly secretory (Fig. 3E). Two secretory regions can be distinguished (Fig. $3 \mathrm{E}$ ), with both secretions presenting a granular aspect. The prostate gland is open to the pallial cavity through its left lateral region where the secretion is highly granular (Figs.

Fig. 2. Echinolittorina peruviana. Photomicrographs of the macroscopic organization of the male reproductive system and histology of the male gonad and seminal vesicle. A. Male removed from shell. B. Organization of the male reproductive system. C. Pattern of heterogeneous distribution of the gonad-digestive gland complex. D. Histological organization of the gonad and seminal vesicle; distribution of the gonadal compartments. E. Serial consecutive sections of (D), stained with PAS-H. PAS reaction positive for glycogen in the interacinar and periacinar compartments, principal flagellar segment, and euspermatozoa in the epithelium of the seminal vesicle. F. Transverse section of the gonadal compartments and seminal vesicle. Spermatogenesis occurs in centripetal form toward the lumen of the acinus. The seminal vesicle contains euspermatozoa stored and organized in bunches associated with paraspermatozoa. The epithelial lining has a vesicular appearance. G. Serial consecutive sections of (F) stained with PAS $\mathrm{H}$. PAS reaction positive for glycogen in the interacinar and periacinar compartments, principal segment of the flagellum of the euspermatozoa, and in the epithelium of the seminal vesicle. H. Serial consecutive sections of $(\mathrm{G})$ and $(\mathrm{F})$ submitted to salivary amylase digestion and then stained with PAS -H. PAS reaction negative for glycogen in the interacinar and periacinar compartments, and the principal segment of the flagellum of the euspermatozoa, and in the epithelium of the seminal vesicle after digestion with amylase. I. Transverse section showing the details of the distribution of the gonadal compartments. J. Consecutive serial sections of (I) stained with PAS-H. PAS reaction positive for glycogen in the interacinar and periacinar compartments, in the principal segment of the flagellae of the euspermatozoa in the gametogenic compartment. PAS reaction negative for the paraspermatozoa. K. Transverse section showing details of the gametogenic acinus, stained with PAS -H. PAS reaction positive in the cytoplasm of the Sertoli-like cells in the gametogenic compartment, and the basal lamina of the periacinar compartment. KEY: apgc - annex penile glandular complex; bl - basal lamina; cm - columellar muscle; dg- digestive gland e - epithelium; f - foot; g gonad; gc - gametogenic compartment; ic - interacinar compartment; me - mantle edge; o - operculum; $\mathrm{p}$ - penis; pg - prostate gland; ps parasperm; s - Sertoli-like cell cytoplasm; sp - sperm; sv - seminal vesicle; $\mathrm{t}$ - tentacle; arrow - periacinar compartment. Scale bars: A, $\mathrm{B}=3 \mathrm{~mm} ; \mathrm{C}=300 \mu \mathrm{m} ; \mathrm{D}, \mathrm{E}=150 \mu \mathrm{m} ; \mathrm{F}, \mathrm{G}, \mathrm{H}=30 \mu \mathrm{m} ; \mathrm{I}=40 \mu \mathrm{m} ; \mathrm{J}=$ $30 \mu \mathrm{m} ; \mathrm{K}=5 \mu \mathrm{m}$. 

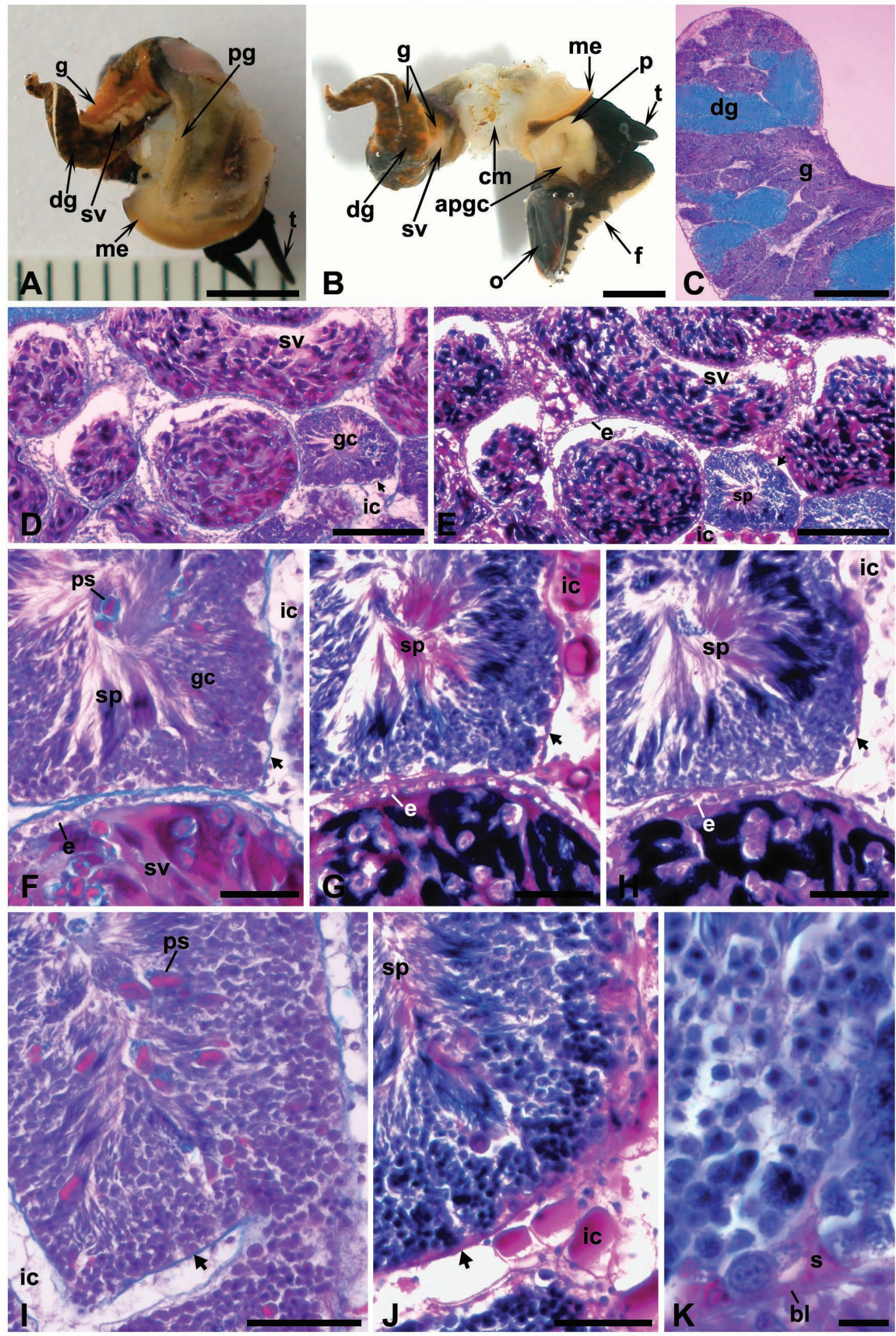


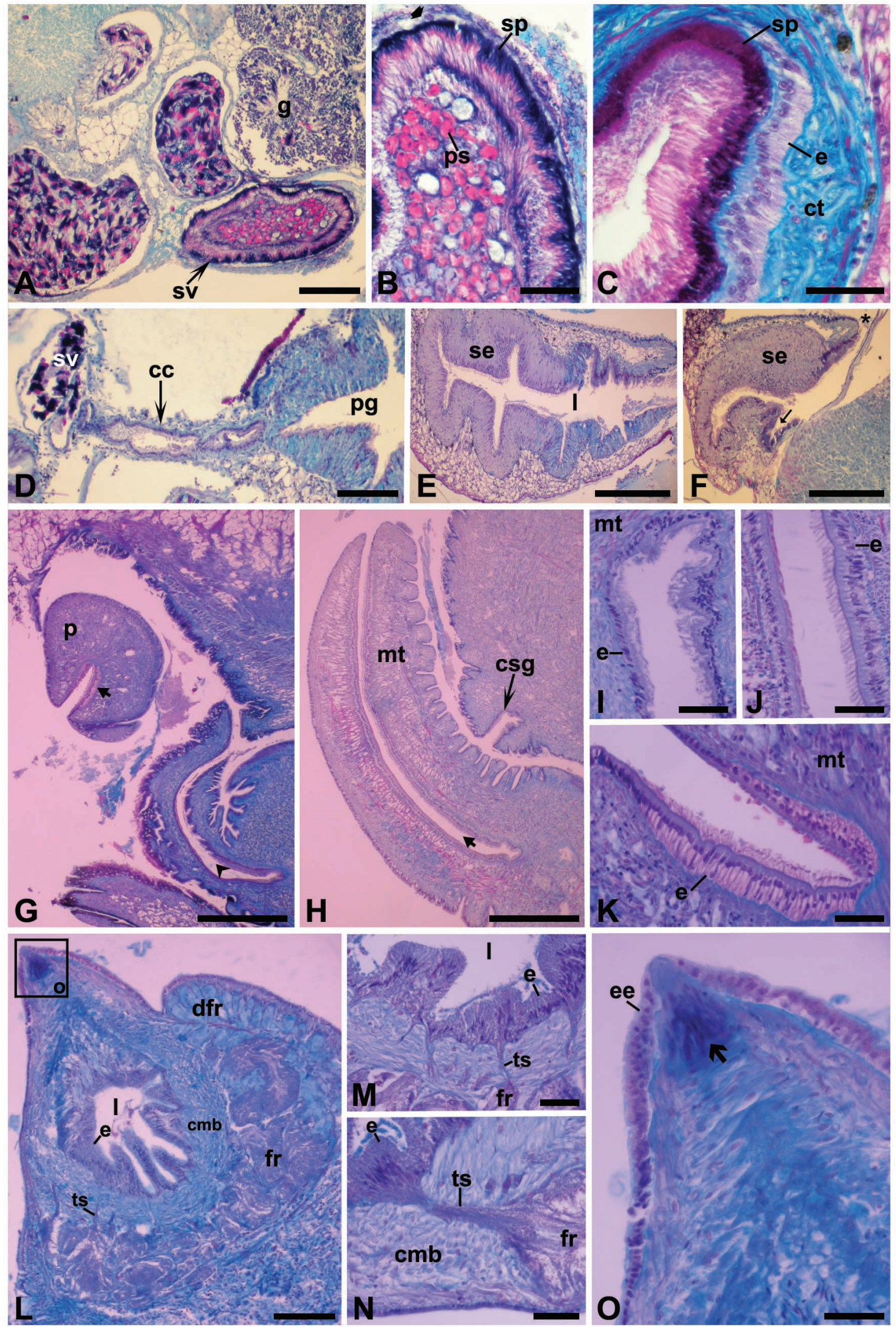


Fig. 3. Echinolittorina peruviana. Photomicrographs of histological sections of the reproductive system. A. Anterior portion of the seminal vesicle showing the organization of the euspermatozoa and paraspermatozoa in this region. B. Organization of the euspermatozoa associated with the epithelial lining (arrow) and paraspermatozoa distributed in the lumen of the anterior portion of the seminal vesicle. C. Seminal receptacle of the female, showing the association of the euspermatozoa with the epithelial lining, which is surrounded by connective - muscular tissue. D. Transverse section, showing the zone of connection between the seminal vesicle and the posterior portion of the prostate gland by means of the connective duct. E. Transverse section of the mid-region of the prostate gland. Note the two secretory zones forming this organ. F. Anterior region of the prostate gland showing the basal canal (arrow), and the opening of this organ to the pallial cavity (asterisk). G. Transverse section of the penis showing the penile spermatic groove (arrow), and longitudinal section of the cervical spermatic groove (arrowhead). H. Sagittal section of the penis showing the penile spermatic groove (arrow) surrounded by muscle tissue, and the cervical spermatic groove in transverse section. I. Transverse section of the cervical spermatic groove surrounded by muscular tissue. J. Sagittal section of the penile spermatic groove, with its ciliated epithelial lining. K. Transverse section of the penile spermatic groove, with detail of its' ciliated epithelial lining. L. Sagittal section of the annex penile complex. A spicule can be observed in the region of the opening of the gland. A connective-muscular tissue band surrounds the gland. M. Transverse section of the mamilliform process showing incorporation of transepithelial secretion. The secretion in the follicular region crosses the connective-muscular tissue band, such that the transepithelial secretion it becomes incorporated in the epithelium that lines the lumen of the mamilliform process. $\mathrm{N}$. Transverse section of the mamilliform process showing in greater detail the incorporation of the transepithelial secretion. Note the secretory constitution of the secretory epithelial lining of the lumen of the mamilliform process and its picnotic nuclei. O. Inset of (L). Spicule in the apex of the mamilliform process (arrow). Note the epithelium lining the exterior of the mamilliform process.

KEY: cc - connection duct; cmb - connective-muscular tissue band; csg - cervical sperm groove; ct - connective tissue; dfr - discoidal follicular region; e - epithelium; ee - external epithelium; fr - follicular region; g - gonad; 1 - lumen; $\mathrm{mt}$ - muscular tissue; $\mathrm{p}$ - penis; $\mathrm{pg}$ prostate gland; ps - parasperm; se - secreting epithelium; sp - sperm; sv - seminal vesicle; ts - transepithelial secretion. Scale bars: $A=$ $100 \mu \mathrm{m} ; \mathrm{B}, \mathrm{C}=30 \mu \mathrm{m} ; \mathrm{D}=100 \mu \mathrm{m} ; \mathrm{E}, \mathrm{F}=200 \mu \mathrm{m} ; \mathrm{G}, \mathrm{H}=300 \mu \mathrm{m}$; $\mathrm{I}, \mathrm{J}, \mathrm{K}=30 \mu \mathrm{m} ; \mathrm{L}=100 \mu \mathrm{m} ; \mathrm{M}, \mathrm{N}=30 \mu \mathrm{m} ; \mathrm{O}=40 \mu \mathrm{m}$.

$3 \mathrm{E}, \mathrm{F})$. This region apparently covers the ventral surface of the pallial cavity, which possesses a simple squamous to cuboidal epithelium (Fig. 3F) projecting itself and forming a structure similar to a groove lined with pseudostratified cylindrical ciliated secretory epithelium (Fig. 3E). In Its anterior section (cephalic direction) the basal region of the groove become modified to a u-shaped form (Fig. 3F) similar to the form of the cervical spermatic groove, while the upper region of the groove is lined with a highly developed epithelium having a high concentration of nuclei in the open region of the pallial cavity (Fig. 3F).
Spermatic groove and penis. As a continuation of the prostate gland, the cervical spermatic groove, which runs along the right lateral border of the neck, is lined with a pseudostratified cylindrical ciliated secretory epithelium surrounded by circular and longitudinal musculature (Figs. 3G, I). The basal cytoplasm appears vesicular, and the apical cytoplasm more compact, with a contrasting staining capacity (Figs. 3I, J). The penis is located at the base of the left eye tentacle, and is a conical, elongated and pointed structure (Figs. 1B; 2B). It is divided into two regions including a wide basal region with a wrinkled aspect, and a pointed apical region (Fig. 1C). The penis is typified by being a muscular organ with circular, longitudinal, and radial to oblique muscle fibers; it is lined externally by a pseudostratified cylindrical ciliated epithelium (Fig. 3H). Beginning at its base, the cephalic spermatic groove continues dorsally along the penis over its entire length (Fig. 1A). The groove is lined with a pseudostratified cylindrical ciliated secretory epithelium (Figs. $3 \mathrm{H}, \mathrm{J}$ ). The nuclei of the epithelial cells in its deepest region are oval to elongated, and are observed to be displaced toward the apical cytoplasm (Figs. 3G, K).

Annex penile glandular complex. This complex is lined by a pseudostratified cylindrical secretory epithelium (Figs. $3 \mathrm{~L}, \mathrm{O})$. It is composed of a mamilliform process and a discoidal contiguous region (Fig. 1C), forming a structure annexed to the penis, although independent of it. Both regions have a follicular organization although with contrasting staining properties (Fig. 3L). The mamilliform process presents a follicular region that completely surrounds its base; adjacent to it is a connective-muscular tissue band, which surrounds the process (Fig. 3L). Continuity is observed between the content of the follicular zone and the basal epithelium of the mamilliform process (Figs. 3L-N). The secreted content crosses the connectivemuscular tissue band reaching the epithelium, which in the intervened zone is characterized by the presence of picnotic nuclei (Fig. 3M, N) and which projects interdigitations of the apical surface, towards the lumen. The intervened epithelium presents a secretion having a granular consistency, and its secretory cells appear highly vesicular toward the apex of the mamilliform process (Fig. $3 \mathrm{~L}$ ). In the zone of the emergence of the process, it is apparent that a large number of nuclei are accumulated in the region of the spicule (Figs. 3L, O).

The discoidal region contiguous with the mamilliform region is composed of a follicular discoidal zone, the cells of which present a granular secretion that apparently envelops the follicular zone at the base of the mamilliform process (Fig. 3L). Both follicular zones possess morphologically similar nuclei. 


\section{DISCUSSION}

In E. peruviana the germinal line in the male gonad is distributed in a centripetal form, similar to that observed in other caenogastropods (Brown). The gonad-digestive gland complex of E. peruviana exemplifies a unique pattern of heterogeneous distribution of the gonadal tissue, in which the acini are branched among the tubules of the digestive gland as previously described for littorinids (Reid, 1989; Fretter \& Graham) and which is not common among the vetigastropodos and caenogastropods. This characteristic gives a variegated aspect to the gonad-digestive gland complex, which is very different from a clear separation between the gonad and the digestive gland into topographically independent areas in other species. On the microscopic level, similarly to other caenogastropods and some vetigastropods (Brown) the male gonad of $E$. peruviana is formed of three compartments: 1) acinar, 2) periacinar and 3) interacinar. Gametogenesis occurs in the gametogenic acini, starting with the germinal cells in interaction with somatic Sertoli-like cells. The acini are surrounded by the periacinar compartment containing fusiform cells that are reminiscent of peritubular myoid cells of the seminiferous tubules of mammals (Russell et al., 1990) and the interacinar compartment, which contains abundant interstitial tissue with the vesicular interstitial cells. These cells carry out an important role in the storage of glycogen, as demonstrated using the PAS technique and digestion with salivary amylase. Subsequently, the products from the gonad of E. peruviana pass to the seminal vesicle, an organ that in the Littorinidae performs the role of storage and resorption of euspermatozoa and paraspermatozoa (Buckland-Nicks et al., 1999; Buckland-Nicks \& Chia, 1976; Linke). One of our observations has shown that it is highly probable that the euspermatozoa become separated from the paraspermatozoa (before their transport to the prostate gland), they become reordered to adopt a distribution similar to that observed in the seminal receptacle of females of this species.

The observation that the euspermatozoa become associated with the internal lining of the seminal vesicle is the first time that this type of organization has been described in the Littorinidae.

In E. peruviana, the euspermatozoan must continue to the prostate gland, which produces at least two types of granular secretions, the functions of which are presently unknown. It has been suggested that the secretion from this organ might have some influence on the separation of the spermatozeugmas (Buckland-Nicks et al.). The organization of the open prostate gland in E. peruviana is similar to that observed in other species of Littorinidae (Reid, 1989) and other mesogastropoda (Fretter). It is probable that the open prostate gland is a primitive character for groups in the Neotaenioglossa (Ponder, 1988). This proposal is in disagreement with the hypothesis of Reid (1989) who suggested that in the Littorinidae the opening of the prostate to the pallial cavity could be functionally important, considering that closed structures (like a tube) as a method of sperm transfer would represent a plesiomorfic condition (Reid, 1989).

Although it is possible that transfer structures organized as grooves imply the loss of gametes being transferred, decreasing the probability of fertilization, the cervical and penile grooves of $E$. peruviana (organized into a ciliated groove surrounded by muscular tissue) are nevertheless similar to those observed in other littorinids (Linke). It has been proposed that the cervical and penile grooves may have a similar evolutionary pathway, suggesting that the muscular action together with the ciliary action in the case of structures organized as grooves, would promote the increase in the speed of movement of the sperm toward the mantle cavity of the female during copulation by animals inhabiting the intertidal region (Reid, 1989).

The glandular complex annexed to the penis that we observed in E. peruviana has been macroscopically described for the genera Nodilittorina, Littoraria (Reid, 2002), Austrolittorina and Afrolittorina (Reid \& Williams, 2004); there is not histological evidence available concerning its organization. Although, a detailed structural study of the mamilliform penile glands lining the ventral edge of the penis as been done in Littorina saxatilis, revealing a similar histological organization and form of secretion from the associated "multicellular" glands (Buckland-Nicks \& Worthen). In E. peruviana the secretion of follicular zone incorporates to the epithelium lining the lumen of the mamilliform process, constituting a granular secretion of "transepithelial" type; similar to the "heterogeneous secretion" observed in L. saxatilis (Buckland-Nicks \& Worthen). It has been suggested that the type of glandular complex as present in E. peruviana, represents a bifurcation of the penis (Jordan \& Ramorino, 1975; Reid, 1989, 2002; Reid \& Williams). Our histological examination suggests that the glandular complex of E. peruviana represents a structure independent of the penis, but located next to it. In species of the genus Littoraria it has been proposed that the glandular complex represents a prehensile penile filament which is maintained within the copulatory bursa of the female during copulation, suggesting that the mamilliform glands have been lost from these species (Buckland-Nicks \& Worthen). Our histological observations suggest that the mamilliform process of $E$. peruviana represents a gland that produces a spicule, the function of which remains unknown. 
Some hypotheses have been proposed concerning the function of mamilliform glands located in a row on the ventral surface of the penis in Littorinidae, where an adhesivetype of role was proposed based on the viscoelastic properties of its secretion (Buckland-Nicks \& Worthen). It has also been proposed that these could maintain the penis in position during copulation (Fretter \& Graham). We were unable to establish the function of the glandular complex in the present study, and for this reason it is important in the future to carry out periodic studies in order to observe functions of this gland as well as a role of the spicule produced by $E$. peruviana. It is also important to carry out histological studies on other genera to ascertain the presence of this glandular complex, and determine what types of secretion are producing other representatives of the Littorinidae.

\section{AKNOWLEDGEMENTS}

This work is part of the undergraduate thesis of the first author. We thank Dr. Louis DiSalvo for suggestions and the English translation of the manuscript. This research was supported by the Grant DIPUV 36/2004, Dirección de Investigación y Postgrado, Universidad de Valparaíso, Chile.

CASTILLO, V. M. \& BROWN, D. I. Anatomía microscópica del sistema reproductor masculino de Echinolittorina peruviana (Mollusca: Caenogastropoda). Int. J. Morphol., 26(2):423-432, 2008.

RESUMEN: Echinolittorina peruviana (Lamarck, 1822), representante gonocórico de Littorinidae en el Pacífico Sur, tiene un sistema reproductor masculino adaptado para la fecundación interna, que en este estudio se describe a niveles macrocoscópico y microscópico; enfatizando la organización compartimentalizada de la gónada y la morfología del pene. El sistema reproductor masculino se presenta como un complejo cónico gónada-glándula digestiva abigarrado. La gónada presenta tres compartimientos: 1) gametogénico acinar entre los acinos glandulares, 2) periacinar con una capa de células somáticas fusiformes y 3) interacinar con células almacenadoras de glicógeno, compartido con los acinos glandulares. En el compartimiento gametogénico acinar ocurre la espermatogénesis con la línea germinal organizada en forma centrípeta hacia el lumen. Hacia anterior, la vesícula seminal almacena los productos de la espermatogénesis; en su región cefálica los euespermatozoides se unen al epitelio y los paraespermatozoides se distribuyen en el lumen. Este órgano se conecta con un conducto corto a la glándula prostática, abierta hacia la cavidad paleal en toda su longitud. La zona anterior de la glándula prostática se une al surco espermático cervical, que recorre el cuello del animal por la región paleal derecha; éste continúa como surco espermático peniano ascendiendo desde su base hasta la punta. El pene es cónico aguzado no pigmentado; hacia anterior adyacente a su base, hay un complejo glandular con un proceso mamiliforme y una región glandular discoidal. Su producto de secreción sería una espícula de función desconocida, cuya histología es descrita por primera vez. En este complejo glandular, el proceso mamiliforme está constituido por la proyección espicular y una banda conjuntivo-muscular que lo rodea y separa de la región glandular folicular discoidal; su secreción atraviesa dicha banda, incorporándose al epitelio de revestimiento interno del proceso.

PALABRAS CLAVE: Mollusca; Anatomía microscópica; Sistema reproductor masculino; Littorinidae.

\section{REFERENCES}

Brown, D. Cambios morfofuncionales en las células somáticas de los compartimientos gonadales durante la expresión gonadal de la sexualidad de Calyptraea (Trochita) trochiformis (Mollusca. Mesogastropoda). Tesis para optar al grado de Magíster, Facultad de Medicina, Universidad de Chile, 1990.

Buckland-Nicks, J.; Bryson, I.; Hart, L. \& Partridge, V. Sex and a snail's sperm: on the transport, storage and fate of dimorphic sperm in Littorinidae. Int. J. Invertebr. Reprod. Dev., 36:145-52, 1999.

Buckland-Nicks, J. A. \& Chia, F. S. Fine structural observations of sperm resorption in the seminal vesicle of a marine snail, Littorina scutulata (Gould, 1849). Cell. Tissue Res., 172(4):503-15, 1976.
Buckland-Nicks, J. \& Worthen. G. Functional morphology of the mammiliform penial glands of Littorina saxatilis (Gastropoda). Zoomorphol., 112:217-25, 1993.

Fretter, V. The genital ducts of some British stenoglossan prosobranchs. J. Mar. Biol. Assoc. U. K., 25:173-211, 1941.

Fretter, V. \& Graham, A. British prosobranch molluscs. Their functional anatomy and ecology. London, Ray Society, 1994.

Gabe, M. Tecniques histologiques. París, Masson et Cie Editeurs, 1968.

Jordan, J. \& Ramorino, L. Reproducción de Littorina (A.) 
CASTILLO, V. M. \& BROWN, D. I. Microscopic anatomy of the male reproductive system in Echinolittorina peruviana (Mollusca: Caenogastropoda). Int. J. Morphol., 26(2):423-432, 2008.

peruviana (Lamarck, 1822) y Littorina (A.) araucana Orbigny, 1840. Rev. Biol. Mar., 15(3):227-61, 1975.

Linke, O. Morphologie und physiologie es genitalsapparates der nordseelittorinen. Wiss. Meeresun., XIX:5-60, 1933.

Pantín, C. Técnicas microscópicas para zoólogos. León, España, Editorial Academia, 1967.

Ponder, W. The truncatelloidean (=rissoacean) radiation - a preliminary phylogeny. Malac. Rev. Suppl., 4:129-46, 1988.

Reid, D. The comparative morphology, phylogeny and evolution of the gastropod family Littorinidae. Phil. Trans. R. Soc. Lond., B324:1-110, 1989.

Reid, D. The genus Nodilittorina von Martens, 1897 (Gastropoda: Littorinidae) in the Eastern Pacific Ocean, with a discussion of Biogeographic provinces of the rocky-shore fauna. The Veliger, 45(2):85-170, 2002.

Reid, D. \& Williams, S. The subfamily Littorininae (Gastropoda: Littorinidae) in the temperate Southern Hemisphere: The genera Nodilittorina, Austrolittorina and Afrolittorina. Rec. of the Australian Museum, 56:75122, 2004.

Russell, L.; Ettlin, R.; Sinha Hikim, A. \& Clegg, E. Histological and histopathological evaluation of the testis. Clearwater, FL, USA, Cache River Press, 1990.

Valderrama, K.; Oliva, M.; Campos, B. \& Brown, D.I. Parasitic castration of Eurhomalea lenticularis (Bivalvia:Veneridae) by a digenetic trematode: Quantitative histological analysis. Dis. Aquat. Org., 59:151-8, 2004.
Correspondence to:

Donald I. Brown

Laboratorio de Biología de la Reproducción

y del Desarrollo

Departamento de Biología y Ciencias Ambientales

Facultad de Ciencias, Universidad de Valparaíso

Casilla 5030,

Valparaíso - CHILE

Email: donald.brown@uv.cl

Received: 26-03-2008

Accepted: 30-04-2008 